\title{
Pharmacological Characterization of the Stick Insect Carausius morosus Allatostatin-C Receptor with Its Endogenous Agonist
}

Ali Işbilir, Burcin Duan Sahbaz, Gunes Tuncgenc, Moritz Bünemann, Martin J. Lohse, and Necla Birgül-Iyison*

Cite This: ACS Omega 2020, 5, 32183-32194

Read Online

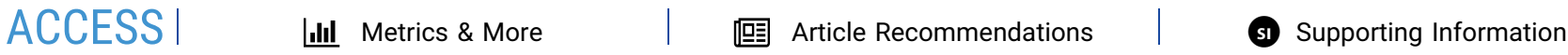

ABSTRACT: G protein-coupled receptors (GPCRs) play a pivotal role in regulating key physiological events in all animal species. Recent advances in collective analysis of genes and proteins revealed numerous potential neuropeptides and GPCRs from insect species, allowing for the characterization of peptide-receptor pairs. In this work, we used fluorescence resonance energy transfer (FRET)-based genetically encoded biosensors in intact mammalian cells to study the pharmacological features of the cognate GPCR of the type-C allatostatin (AST-C) peptide from the stick insect, Carausius morosus. Analysis of multiple downstream pathways revealed that AST-C can activate the human $\mathrm{Gi}_{2}$ protein, and not Gs or Gq, through AST-C receptor (AlstRC). Activated AlstRC

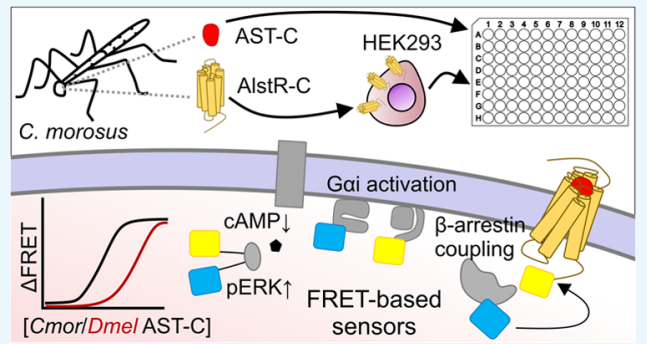
recruits $\beta$-arrestin2 independent of the Gi protein but stimulates ERK phosphorylation in a Gi protein-dependent manner. Identification of G $\alpha \mathrm{i}$-, arrestin-, and GRK-like transcripts from $C$. morosus revealed high evolutionary conservation at the $\mathrm{G}$ protein level, while $\beta$-arrestins and GRKs displayed less conservation. In conclusion, our study provides experimental and homology-based evidence on the functionality of vertebrate $G$ proteins and downstream signaling biosensors to characterize early signaling steps of an insect GPCR. These results may serve as a scaffold for developing assays to characterize pharmacological and structural aspects of other insect GPCRs and can be used in deorphanization and pesticide studies.

\section{INTRODUCTION}

Neuropeptides play a central role in vital physiological processes in vertebrates as well as insects. ${ }^{1}$ These peptides exert their biological activities through $G$ protein-coupled receptors (GPCRs) on their target cells. ${ }^{2}$ Both human and insect GPCRs share significant structural homology and may therefore display common mechanisms of activation. ${ }^{3}$

Deorphanization and characterization of insect GPCRs provide a better understanding of insect physiology from the larval to the adult stage. Within the last two decades, genome-, ${ }^{4,5}$ transcriptome-, ${ }^{6,7}$ and proteome-based ${ }^{8,9}$ studies on several insect species identified numerous neuropeptides and GPCRs, which provided a large database for studying neuropeptide-receptor pairs. Measuring $\mathrm{Ca}^{2+}$ release in exogenous systems is a widely used approach to characterize insect GPCRs. Although this method robustly serves to characterize the neuropeptide-receptor pharmacology, it is promiscuous and is placed downstream of G proteins. Thus, it fails to report the $G$ protein specificity of a receptor. ${ }^{2}$ At the vertebrate end of the GPCR spectrum, fluorescence and bioluminescence resonance energy transfer (FRET and BRET)-based, genetically encoded biosensors can measure receptor downstream signaling robustly. These sensors are extensively used for identifying the pharmacology and signaling by ligands, ${ }^{10,11}$ kinetic properties of receptor-mediated signaling, ${ }^{12}$ as well as deorphanization and characterization of
GPCRs. ${ }^{13}$ Due to a high degree of homology between human and insect GPCRs, vertebrate signaling protein-based biosensors may also be functional for characterizing insect receptors. In accordance, few reports have used such tools to study insect receptor signaling. ${ }^{14-16}$

Among insect neuropeptides, allatostatins (ASTs) were discovered as inhibitors of juvenile hormone $(\mathrm{JH})$ synthesis in the neuroendocrine glands, namely, $C$. allata and Corpora cardiaca. ${ }^{17,18}$ AST-C inhibits JH synthesis ${ }^{19,20}$ and modulates muscle contractility, ${ }^{21}$ nociception, ${ }^{22}$ and circadian cycle. ${ }^{23}$ Analogues of AST-C have been shown to inhibit the feeding behavior in aphids, ${ }^{24,25}$ offering a potential use of AST-Cs and their receptors for the regulation of insect behavior.

AST-Cs bind and activate class A GPCRs, named AST-C receptors (AlstRCs). The human homologue of AlstRCs is somatostatin receptors, which primarily inhibit growth hormone synthesis and secretion, ${ }^{26}$ and regulate feeding and drinking behavior ${ }^{27}$ in mammals. Somatostatin receptors inhibit adenylyl cyclase (AC) by activating the $\mathrm{Gi}$ protein

Received: July 15, 2020

Accepted: November 4, 2020

Published: December 8, 2020 
and also activate the mitogen-activated protein kinase pathway. ${ }^{28}$

The Indian stick insect Carausius morosus (Cmor) is a model organism used to study motor control ${ }^{29-31}$ and neurohormone-regulated mechanisms. ${ }^{32-34}$ Two recent studies revealed numerous GPCRs and neuropeptides of Cmor, ${ }^{35,36}$ which offers a great potential for characterizing receptorneuropeptide pairs of this species.

Previously, we have identified CmorAlstRC and described the binding of a Manduca sexta AST-C to it. ${ }^{37}$ In this study, using genetically encoded biosensors, we characterize CmorAlstRC with its native agonist in terms of downstream signaling. Our results describe the ligand-binding domains on CmorAlstRC that modulate its signaling outcome. We finally demonstrate that a number of genetically encoded FRETbased biosensors that report the activation of intracellular signaling pathways, as well as fluorescently labeled mammalian $\mathrm{G}$ proteins and arrestins, can be used to study the signaling properties of insect GPCRs.

\section{MATERIALS AND METHODS}

DNA Constructs. G $\beta-2 \mathrm{~A}-\mathrm{cpV}-\mathrm{G} \gamma 2$-IRES-G $\alpha \mathrm{i} 2-\mathrm{mTq} 2$ (G $\alpha$ i2 FRET sensor) and Gq FRET sensors were a gift from Dorus Gadella ${ }^{38}$ (Addgene plasmid \#69624 and \#137810). Cytoplasmic and nuclear EKAR (Cerulean-Venus) (cytoEKAR, nucEKAR) were gifts from Karel Svoboda ${ }^{39}$ (Addgene plasmid \#18681). Epac-S ${ }^{\text {H187 }}$ biosensor was kindly provided by Kees Jalink. ${ }^{40}$ pCMV5- $\alpha$ 1a AR plasmid was a gift from Robert J. Lefkowitz (Addgene plasmid \#45760). ${ }^{41}$

The CamAlstRC in pcDNA3 (CamAlstRC wt) is described elsewhere. ${ }^{37}$ The C-terminally EYFP-tagged CamAlstRC construct (CamAlstRC-EYFP) was generated by amplifying the CamAlstRC gene using the forward 5'-CCCAAGCTTATGTCTGTGGAACAAGTGACG- $3^{\prime}$ and the reverse $5^{\prime}$ TGCTCTAGACACCTGGGTCGGCTGCTG-3' primers, digesting the PCR product and the $\beta_{2}$ AR-EYFP using HindIII and $X b a \mathrm{I}$ restriction enzymes, and inserting the digested PCR product of CamAlstRC in the EYFP-carrying vector backbone. ECL3 ${ }^{293-298} \mathrm{Ala}$ and $\Delta \mathrm{N}$-term mutants (constructs with and without the C-terminal EYFP tag) were generated using the Q5 Site-Directed Mutagenesis Kit (New England Biolabs, E0554S), using the primers 5'-CCGACACTGCTGCTGATC$3^{\prime}$ and $5^{\prime}$-AAGCTTGGGTCTCCCTATAG-3' for the $\Delta \mathrm{N}$ term mutation and $5^{\prime}$ - ctgcagctgcGTGCCAGTCGAGGGTGTC-3' and 5' - ctgcagctgcTGAGCGCCATCTGCGTGA-3' for the ECL $3^{293-298}$ Ala mutation.

The other constructs used in FRET microscopy experiments were human $\mathrm{G} \alpha \mathrm{i}_{2}$-ECFP, human $\mathrm{G} \beta_{1}$-wt, bovine $\mathrm{G} \gamma_{2}{ }^{4242}$ and human $\beta$-arrestin2-ECFP. ${ }^{43}$

Peptides. Norepinephrine (NE) was purchased from Sigma-Aldrich (Germany). C. morosus AST-C (with Cterminal amidation) was custom-synthetized by GenScript. Drosophila melanogaster pGlu AST-C peptide (Phoenix Pharmaceuticals, \#047-97) and allatostatin 3 (AST-A, Phoenix Pharmaceuticals, \#047-16) were utilized in FRET experiments. Peptides were dissolved in $0.1 \%(\mathrm{w} / \mathrm{v})$ bovine serum albumin (BSA)-containing $1 \times$ phosphate-buffered saline (PBS). Further, $0.1 \%(\mathrm{w} / \mathrm{v})$ BSA-containing PBS was used as the vehicle.

Cell Culture and Transfection. HEK293 cells were cultured in DMEM (PAN Biotech, Germany) containing 4.5 $\mathrm{g} / \mathrm{L}$ glucose, 10\% FBS, $2 \mathrm{mM}$ L-glutamine, penicillin $(50 \mathrm{mg} /$ $\mathrm{mL})$, and Streptomycin $(50 \mathrm{mg} / \mathrm{mL})$ at $37{ }^{\circ} \mathrm{C}$ in a $5 \% \mathrm{CO}_{2}$ incubator. Cells were routinely checked for mycoplasma contamination using the MycoAlert Mycoplasma Detection Kit (Lonza, Germany). Cells were seeded in 6 or $10 \mathrm{~cm}$ cell culture dishes prior to transfection. Transfections were performed using Effectene transfection reagent (QIAGEN, Germany) according to the manufacturer's instruction.

For FRET microscopy, HEK293 cells grown in $6 \mathrm{~cm}$ dishes were transfected. For plate reader FRET experiments, HEK293 cells were seeded in $10 \mathrm{~cm}$ plates. For all FRET experiments, the cell culture medium was replaced $16 \mathrm{~h}$ after transfection. FRET measurements were performed $36-48 \mathrm{~h}$ after transfection.

Immunocytochemistry and Microscopy. HEK293 cells were seeded in 6-well plates on poly-L-lysine (PLL, SigmaAldrich, Germany)-coated coverslips and transfected as described above. The cells were washed once with prewarmed $1 \mathrm{X}$ PBS $24 \mathrm{~h}$ after transfection and fixed with $1 \mathrm{~mL}$ of ice-cold 4\% PFA for $20 \mathrm{~min}$ at room temperature and then washed three times with warm 1× PBS. 1× CellMask Deep Red (Thermo Fisher Scientific) and Hoechst 33342 solution (Thermo Fisher Scientific) were used according to the manufacturer's protocols to label the cell membrane and nucleus, respectively.

Labeled cells on coverslips were mounted on glass slides using the VectaShield Antifade Mounting Medium (Vector Laboratories). Samples were imaged using a Leica TSC SP8 confocal microscopy setup equipped with an HC PL APO $40 \times / 1.30$ Oil CS2 objective. Localization of CamAlstRC was imaged via illumination of EYFP $\left(\lambda_{\mathrm{ex}} / \lambda_{\mathrm{em}}: 514 / 518-580 \mathrm{~nm}\right)$, the cell membrane was imaged via CellMask $\left(\lambda_{\mathrm{ex}} / \lambda_{\mathrm{em}}: 649 /\right.$ 655-700 nm), and the nuclei were imaged via Hoechst 33342 stain (UV laser, $\lambda_{\text {ex }} / \lambda_{\text {em }}: 405 / 460-490 \mathrm{~nm}$ ). Images were obtained with the LAS X software in a $1024 \times 1024$ pixel format, consisting of 4 averaged line scans. The scan speed was set to $400 \mathrm{~Hz}$, and the pinhole was set to Airy 1 .

FRET Microscopy. Transfected cells were reseeded on PLL-coated $24 \mathrm{~mm}$ glass coverslips in 6-well plates. On the day of measurement, coverslips with transfected cells were placed in an imaging chamber and maintained in FRET buffer (137 $\mathrm{mM} \mathrm{NaCl}, 5.4 \mathrm{mM} \mathrm{KCl}, 10 \mathrm{mM}$ HEPES, $2 \mathrm{mM} \mathrm{CaCl}_{2}, 1 \mathrm{mM}$ $\mathrm{MgCl}_{2}$ in ultrapure water, $\mathrm{pH}$ 7.35). For each coverslip, a single cell was imaged. During all measurements, the measured cell was continuously perfused with FRET buffer and/or ligand solution, using a perfusion system with a valve controller (AlaVC3-8SP; ALA Scientific Instruments, Farmingdale). All measurements were performed on an Axiovert 100 inverted fluorescence microscope (Zeiss, Germany) equipped with Plan/Apo N $60 \times / 1.45$ Oil (Nikon, Japan). For FRET measurements, cells were excited at $440 \mathrm{~nm}$ (PrecisExcite100, CoolLED, U.K., and excitation filter $436 / 20 \mathrm{~nm}$, Chroma) for $60 \mathrm{~ms}$ at $1 \mathrm{Hertz}(\mathrm{Hz})$ frequency. FCFP (480 $\mathrm{nm}$, CFP emission) and FYFP (535 nm, YFP emission) were recorded simultaneously at $470 / 24 \mathrm{~nm}$ and $525 / 39 \mathrm{~nm}$ (Chroma), and a CCD-camera (SPOT Imaging Solutions) using the VisiView software (Visitron, Germany)

Background fluorescence, YFP emission, and CFP spillover on the YFP channel were corrected as described previously. ${ }^{44}$

FRET was calculated as the ratio of corrected YFP and CFP signals. FRET traces from individual cells were normalized to the baseline ratio, and each normalized trace was averaged to show the relative changes in FRET in response to ligands.

FRET-Based Plate Reader Assay. HEK293 cells transfected with CmorAlstRC variants with $\mathrm{G} \alpha$ sensors were reseeded in black-bottom 96-well plates (Corning) as 75.000 
per well. FRET measurements were performed using a Biotek Synergy Neo2 Multi-Mode Reader, and data was acquired using Gen5 software (Biotek, Germany). For the measurements, DMEM was replaced with $90 \mu \mathrm{L}$ of HBSS. Measurements were performed using dual monochromators for excitation and emission, and dual PMTs were used for fluorescence detection. For CFP, excitation and emission bandwidth were set to $434 / 20$ and $490 / 20$, respectively. FRET was recorded using the second monochromators, with the bandwidth settings of $434 / 20$ and $540 / 25$ for excitation and emission, respectively. The voltage gain for both PMTs was set to 100 . A xenon lamp was set to low-energy mode, read height was set to $4.5 \mathrm{~mm}$, and read speed was set to normal. Data points for each well were generated with $90 \mathrm{~s}$ intervals. Four data points per well were measured for the baseline. After the baseline measurement, cells were stimulated manually with the ligands using a multichannel pipette, and 5 more data points were acquired per well. For each concentration, 8 wells were used and the results were averaged.

FRET was calculated as the ratio of FRET and CFP values for each data point of each well. FRET changes due to different concentrations of the ligand ( $\% \triangle \mathrm{FRET}$ ) were calculated using the following formula

$$
\% \triangle \text { FRET }=\left(\frac{\text { average }_{\text {post }}-\text { average }_{\text {pre }}}{\text { average }_{\text {pre }}}\right) \times 100
$$

Transcript Identification and Phylogenetic Analysis. Transcripts encoding for C. morosus G $\alpha$ i, arrestin, and GRK were searched within Transcript Shotgun Assembly (TSA) databases using NCBI tblastn tool (https://blast.ncbi.nlm.nih. gov/Blast.cgi). To search for G $\alpha$ i, arrestin, and GRK transcripts, human $\mathrm{G} \alpha \mathrm{i} 2$ (UniProtKB: P04899), human $\beta$ arrestin2 (UniProtKB: P32121), and human GRK2 (UniProtKB: P25098) were used, respectively, as queries. From the obtained hits, transcripts encoding to proteins with the highest sequence similarity were selected. The chosen transcripts were translated to protein, and the obtained protein sequences were used as a query on NCBI BLASTp to find whether they display any homology to their insect counterparts.

To generate phylogenetic trees, G $\alpha \mathrm{i}$, arrestin, and GRK proteins from various insect and vertebrate species were obtained using C. morosus $\mathrm{G} \alpha \mathrm{i}$, arrestin, and GRK, respectively, as query entries on BLASTp, and the protein database was restricted to selected species. From the results, one isoform of each protein from each species was selected based on maximum sequence identity to the query. Phylogenetic trees were generated using NGPhylogeny tool ${ }^{45}$ (https:// ngphylogeny.fr/) FastME protocol with default settings.

Statistical Analysis. All data analysis was performed using GraphPad 5.0 software (San Diego). All data represent the average of individual recordings with the standard deviation or the standard error of the mean (SEM) of $n$ individual cells for FRET microscopy experiments and $n$ individual plates for plate reader experiments. Concentration-response curves were generated by fitting a three-parameter Hill equation. An extra-sum-of-squares $\mathrm{F}$ test was performed to compare the EC50 and $E_{\max }$ parameters of the fitted concentrationresponse curves. A statistical difference between these parameters was accepted as significant at $P<0.05$.

\section{RESULTS}

CmorAlstRC Is Localized to the Plasma Membrane of HEK293 Cells. To characterize the subcellular localization of CmorAlstRC, we cloned a construct with the EYFP-encoding gene fused to the C-terminus of the receptor (CmorAlstRCEYFP), expressed it in HEK293 cells, and labeled the nucleus and cell membrane of these cells to distinguish the receptor localization. Live-cell confocal microscopy imaging showed that the fluorescence signal from EYFP was predominantly colocalized with the cell membrane marker, indicating that CmorAlstRC mainly resides on the cell membrane (Figure 1).
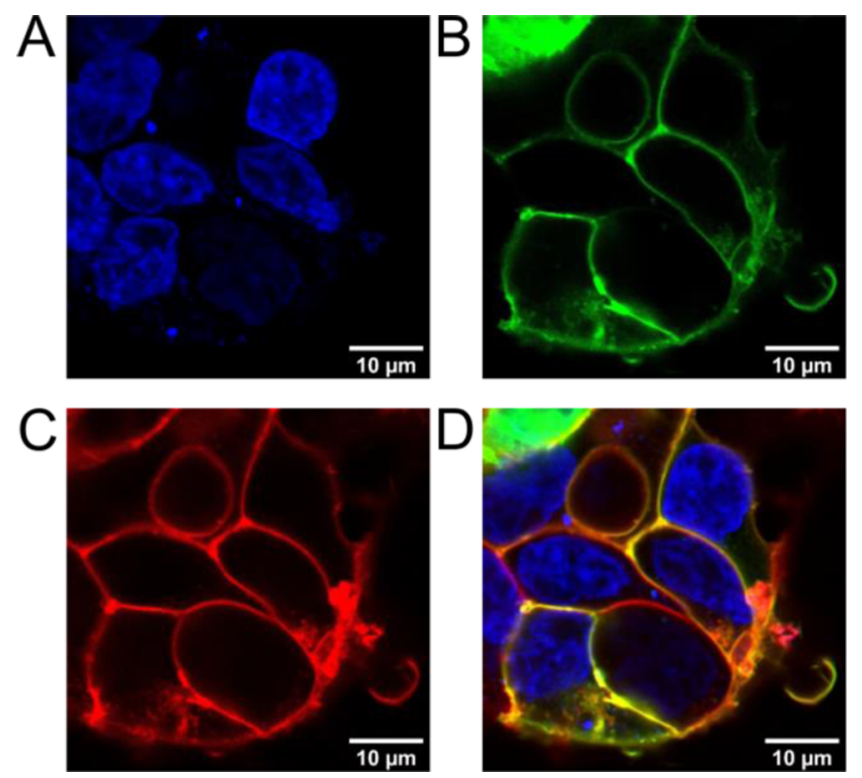

Figure 1. CamAlstRC-EYFP localizes to the cell membrane of HEK293 cells. Confocal microscopy images of HEK293 cells transfected with (B) CamAlstR-EYFP (green). (A) Nuclei are stained with Hoechst 33342 (blue) and (C) cell membrane is stained with CellMask Deep Red (red). Merged image (D) represents the overlay of three images of different stainings. The image is representative of three independent experiments.

CmorAlstRC Activates $\mathbf{G} \mathrm{i}_{2}$ in HEK293 Cells. The amino acid sequence of a potential CmorAST-C peptide was previously described as RSYWKQCAFNAVSCF-amide via transcriptomic and proteomic analyses. ${ }^{35}$ This peptide is $100 \%$ identical with the AST-C peptides from a number of ant, aphid, and crustacean species (Table S1). To assess whether this peptide can activate CmorAlstRC, we used genetically encoded FRET-based biosensors that report the activation of $\mathrm{G} \alpha \mathrm{i}, \mathrm{G} \alpha \mathrm{q}$ proteins, as well as the $\mathrm{G} \alpha \mathrm{s}$-mediated cAMP accumulation.

To measure the G $\alpha \mathrm{i}$ and $\mathrm{G} \alpha \mathrm{q}$ activation, we used two FRET sensors that are based on rearrangements/dissociation between $\mathrm{G} \alpha \mathrm{i} / \mathrm{q}$ and $\mathrm{G} \beta \gamma$ subunits tagged with donor and acceptor fluorophores. Upon receptor-mediated $\mathrm{G}$ protein activation, a decrease in FRET is observed (Figure 2A). We co-transfected HEK293 cells with G $\alpha \mathrm{i}_{2}$ FRET biosensor ${ }^{38}$ and CmorAlstRC or CXCR4 and measured FRET in 96-well plates. Here, CXCR4 served as a positive control for $\mathrm{G} \alpha \mathrm{i}_{2}$ activation. For both receptor $+\mathrm{G} \alpha \mathrm{i}_{2}$ sensor combinations, we observed a concentration-dependent decrease in FRET, with a pEC50 value of $9.49 \pm 0.1(\mathrm{SD})$ for CXCR4+CXCL12 and $\mathrm{pEC50}=$ $9.63 \pm 0.16$ for CmorAlstRC + AST-C (Figure 2B). No 
A

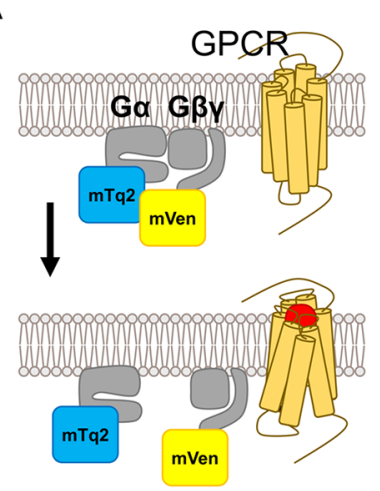

B
B Gai activation

- CXCR4 + CXCL12

- CmorAlstRC + AST-C

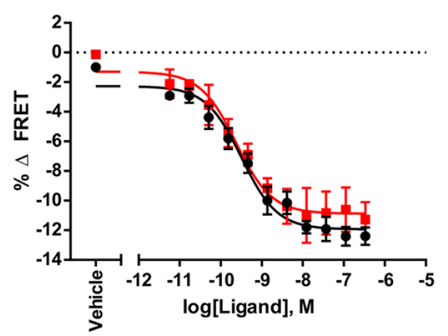

D

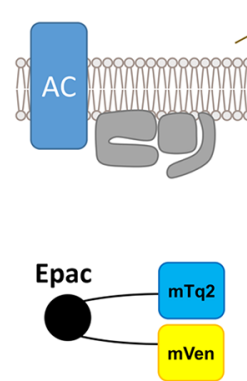

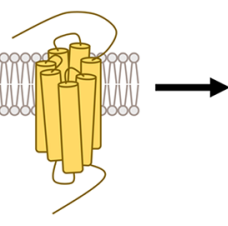

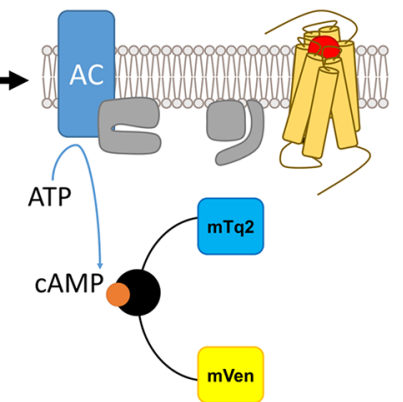

C Gaq activation

- $\alpha_{1 A} A R+N E$

- CmorAlstRC + AST-C

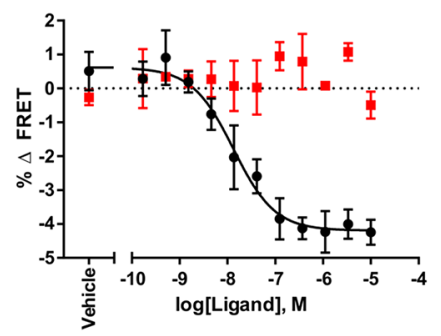

E CAMP production

$\rightarrow \beta_{1} A R+N E$

- CmorAlstRC + AST-C

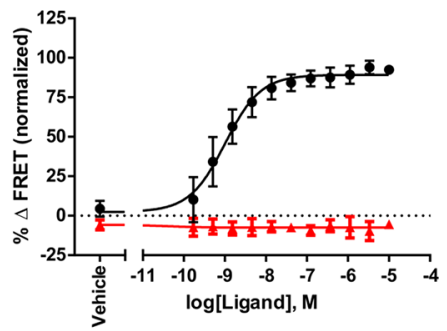

Figure 2. FRET demonstrates that CmorAlstRC activates $\mathrm{G} \alpha \mathrm{i}$ but not $\mathrm{G} \alpha \mathrm{q}$ or $\mathrm{G} \alpha \mathrm{s}$. (A) Schematic representation of the working mechanism of FRET-based $\mathrm{G}$ protein activation biosensors. At the resting state, mTurquoise2 (mTq2)-tagged $\mathrm{G} \alpha$ and $\mathrm{mVenus}$ (mVen)-tagged $\mathrm{G} \beta \gamma$ subunits are in close proximity (high FRET). Agonist binding to the GPCR activates the G protein biosensor, leading to a decrease in FRET. (B and C) FRETbased measurement of $\mathrm{G} \alpha \mathrm{i}_{2}$ (B) and $\mathrm{G} \alpha \mathrm{q}$ (C) activation in a 96-well format. Concentration-response curves were obtained by stimulation of the receptors with the different concentrations of their agonists (indicated as Receptor name + Agonist name). Data represents the mean and standard error of the mean (SEM) from three to four independent plate reader experiments. (D) Working mechanism of the FRET-based Epac-S ${ }^{\mathrm{H} 187}$ sensor. Agonist binding to the GPCR activates the G $\alpha$ s protein, which in turn activates adenylyl cyclase (AC) that converts intracellular ATP to cAMP (orange circle). cAMP binding to the Epac domain (black circle) of the Epac-S ${ }^{\mathrm{H} 187}$ sensor undergoes a conformational change that induces a decrease in FRET. (E) Concentration-response relation of AST-C or NE-induced cAMP production. HEK293 cells expressing Epac-S ${ }^{\mathrm{H} 187}$ sensor with CamAlstRC or $\beta_{1} \mathrm{AR}$ were stimulated with increasing concentrations of AST-C or NE. Data represents the average with the SEM of at least three individual experiments. Data was normalized to the minimum and maximum values observed in cumulative data.

response was observed for $1 \mu \mathrm{M}$ AST-A (Figure S1A) in cells expressing CmorAlstRC and the G $\alpha \mathrm{i}_{2}$ sensor. Cells transfected with an empty vector (pcDNA3), instead of CmorAlstRC, did not result in any FRET change by AST-C (Figure S1B). On the other hand, AST-C stimulation of CmorAlstRC did not activate the G $\alpha \mathrm{q}$ FRET sensor, ${ }^{46}$ while the norepinephrine (NE) stimulation of the $\alpha_{1 \mathrm{~A}}$ adrenergic receptor $\left(\alpha_{1 \mathrm{~A}} \mathrm{AR}\right)$ induced a concentration-dependent FRET decrease in the G $\alpha \mathrm{q}$ sensor (Figure 2C).

Next, we used the Epac- $S^{\mathrm{H} 187}$ FRET sensor ${ }^{40}$ to measure intracellular cAMP levels, as an indirect indicator of G $\alpha \mathrm{s}$ protein-mediated adenylyl cyclase activation. ${ }^{47}$ This biosensor is based on the cAMP-binding Epac1 protein, placed between donor and acceptor fluorescent proteins. Upon binding to cAMP, the distance between the fluorophores in the biosensor increases, resulting in decreased FRET. Therefore, any decrease in intracellular cAMP would result in an increased FRET signal (Figure 2D). In cells co-expressing the CmorAlstRC and Epac- $\mathrm{S}^{\mathrm{H} 187}$ sensor, AST-C did not induce any change in the FRET signal, while NE stimulation of the cells co-expressing the $\beta_{1}$ adrenergic receptor $\left(\beta_{1} \mathrm{AR}\right)$ decreased the FRET response (increased the cAMP level) in a NE concentration-dependent manner (Figure 2E).
Together, these experiments suggest that the AST-C stimulation of CmorAlstRC can activate the $\mathrm{G} \alpha \mathrm{i}_{2}$ protein, but not $\mathrm{G} \alpha \mathrm{q}$ or $\mathrm{G} \alpha$ s protein, and the Gi activation by AST-C is only mediated through CmorAlstRC in HEK293 cells.

CmorAlstRC Couples to ${\mathrm{G} \alpha \mathrm{i}_{2}}_{2}$ in HEK293 Cells. After identifying that CmorAlstRC can activate ${\mathrm{G} \alpha \mathrm{i}_{2}}_{2}$ protein, we measured whether CmorAlstRC and $\mathrm{G} \alpha \mathrm{i}_{2}$ can directly interact. Therefore, we performed time-lapse FRET microscopy in live single HEK293 cells expressing CmorAlstrRC-EYFP and the C-terminally ECFP-tagged $\mathrm{G} \alpha \mathrm{i}_{2}$ subunits, alongside $\mathrm{G} \beta_{1}$ and $\mathrm{G} \gamma_{2}$, for optimal $\mathrm{G}$ protein heterotrimer stoichiometry (Figure 3A). Using a multireservoir perfusion tip, we applied stimulus and wash-off cycles with different AST-C concentrations. This experiment revealed a dose-dependent, reversible interaction of CmorAlstRC with $\mathrm{G} \alpha \mathrm{i}_{2}$ (Figure 3B,C). A fast acquisition mode $(5 \mathrm{~Hz})$ allowed monitoring apparent coupling and dissociation kinetics between CmorAlstrRC-EYFP and G $\alpha \mathrm{i}_{2}$-ECFP with 1 $\mu \mathrm{M}$ AST-C (Figure 3D). We obtained an association speed of $\tau=227$ (161-303 (Confidence Interval, CI)) ms (Figure 3E), and dissociation kinetics was $\tau=3.8(3.2-4.7 \mathrm{CI}) \mathrm{s}$ (Figure $3 \mathrm{~F})$. These findings confirm that CmorAlstRC can rapidly and reversibly couple with human ${\mathrm{G} \alpha \mathrm{i}_{2}}_{2}$.

CmorAlstRC Inhibits Intracellular cAMP Production. To corroborate Gi protein preference of CmorAlstRC, we 
A

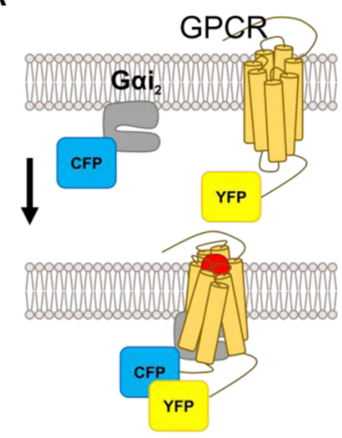

D

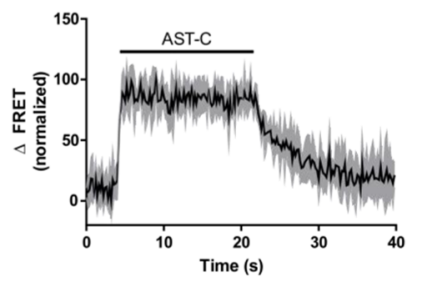

B

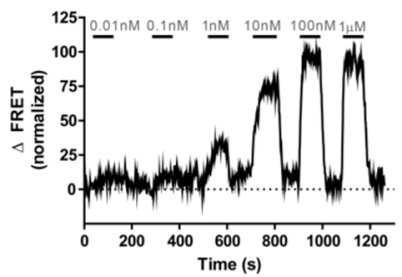

E

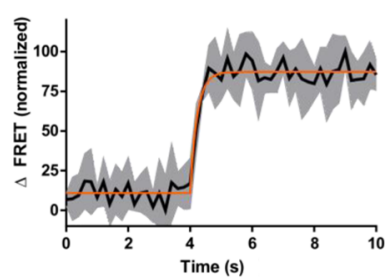

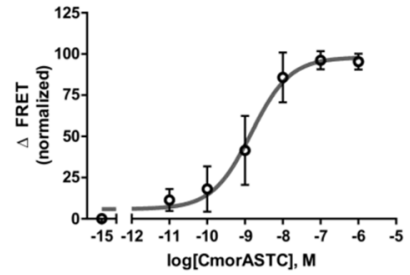

C

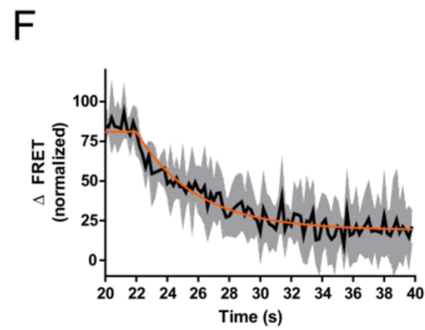

Figure 3. FRET demonstrates that CmorAlstRC is a Goi-coupling GPCR. (A) Schematic representation of the FRET experiments measuring interactions between CmorAlstRC (orange bundles) tagged with a C-terminal EYFP (yellow box) and C-terminally ECFP (blue box)-tagged G $\alpha_{2}{ }_{2}$ (purple). The upper panel represents the inactive CmorAlstRC. The lower panel represents the ligand (red box)-bound active receptor. (B) A representative FRET trace of the experiment depicted in (A). A single cell expressing CmorAlstRC-EYFP + G $\alpha$ i2-ECFP is subjected to superfusion with varying AST-C concentrations (durations and concentrations are shown above the trace) and washed-out. Data was normalized to the first and maximum values within the data set. (C) Dose-response relation of CmorAlstRC-EYFP + G $\alpha$ i2-ECFP interactions as a measure of FRET changes. Each data point represents the average of maximum responses observed at each concentration. Error bars represent the SD of nine independent measurements. Dose-response curve-fitting on GraphPad Prism resulted in a pEC50 value of $8.84 \pm 0.11$ (SD) and an $\mathrm{R}^{2}$ of 0.9186 . (D) Kinetic FRET trace of CmorAlstRC-EYFP + G $\alpha$ i2-ECFP interactions with high-speed acquisition $(50 \mathrm{~Hz})$. Eight independent single-cell traces were normalized to the minimum and maximum values and averaged to generate the represented trace. (E and F) Zoomed-in view of the trace on (D). The orange line is the fit generated by «Plateau followed by one phase decay» function on GraphPad Prism to calculate the tau $(\tau)$ values of receptor-G protein association (E) and dissociation (F). Error bars (gray) represent the SD of nine independent measurements.

again used the Epac-S ${ }^{\mathrm{H} 187}$ FRET sensor to measure intracellular cAMP. We first expressed CmorAlstRC and Epac-S ${ }^{\mathrm{H} 187}$ constructs in HEK293 cells and measured single-cell time-lapse FRET. Using a perfusion tip, we first continuously applied 3 $\mathrm{nM}$ isoprenaline (Iso), a $\beta$-adrenoreceptor ( $\beta$-AR) agonist that stimulates cAMP production. As a result of this stimulation, we observed a sharp decrease in FRET, indicating endogenous $\beta$ AR activation, thus intracellular cAMP production. Following this, we challenged the continuous Iso stimulation with simultaneous $1 \mu \mathrm{M}$ AST-C superfusion. AST-C was able to reverse the decrease in the FRET signal, indicating that it inhibited cAMP production stimulated by Iso (Figure 4A).

We also tested whether the cAMP inhibition assay can be performed in a microtiter plate format. Cells expressing CmorAlstRC and Epac-S $\mathrm{S}^{\mathrm{H} 187}$ were pooled in 96-well plates, pretreated with $1 \mu \mathrm{M}$ Forskolin (Fsk), which stimulates adenylyl cyclases (ACs) and increases intracellular cAMP levels. In these experiments, AST-C concentration-dependently decreased Fsk-induced cAMP levels (pEC50: 8.72 \pm 0.06 $(\mathrm{SD}))$. We repeated this assay in the presence of Pertussis Toxin (PTx), an inhibitor of Gi protein activity. ${ }^{48}$ PTx completely abrogated the AST-C-mediated cAMP inhibition (Figure 4B). These results supported that AST-C and CmorAlstRC can inhibit AC activity in a PTx-dependent manner.

$\mathrm{N}$-Terminus and ECL3 of CmorAlstRC Contribute to Signaling Efficacy and Potency. Our previous model of CmorAlstRC with AST-C suggested that the third extracellular loop (ECL3) and N-terminal domains were important for ligand binding. ${ }^{37}$ To test the contribution of these domains to receptor signaling, we expressed different CmorAlstRC mutants with the G $\alpha \mathrm{i}_{2}$ FRET sensor in HEK293 cells and measured FRET in 96-well plates. On one mutant, the residues between 293 and 298 were substituted with alanines $\left(\mathrm{ECL}^{293-298} \mathrm{Ala}\right)$. On the other mutant, N-terminal 52 residues were deleted $(\Delta \mathrm{N}$-term $)$. These mutations did not cause a remarkable impairment of the receptor localization on the cell membrane (Figure S2A-D). AST-C stimulation of the cells expressing the wild-type (WT) CmorAlstRC and the G $\alpha \mathrm{i}_{2}$ sensor yielded a concentration-dependent response with a pEC50 value of $9.24 \pm 0.08$ (SD; Figure 4C). Compared to the wild-type (WT), the $\Delta \mathrm{N}$-term mutant produced a significantly decreased potency and efficacy in G $\alpha \mathrm{i}_{2}$ activation. On the other hand, the ECL3 ${ }^{293-298}$ Ala variant also displayed a lower potency, but the maximum response was similar to that of the WT receptor (Figure 4C and Table S2A,B).

To further understand the basis of the decreased potency by mutants, we also tested an AST-C from D. melanogaster (DmelASTC) on CmorAlstRC. On the 96-well plate format $\mathrm{G} \alpha \mathrm{i}_{2}$ assay, DmelASTC-induced $\mathrm{G} \alpha \mathrm{i}_{2}$ activation displayed a lower potency compared to CmorAST-C peptide. On the $\Delta \mathrm{N}$ term variant, we observed a decrease in efficacy, while the EC50 did not differ when compared to the WT receptor. On the other hand, the ECL3 ${ }^{293-298} \mathrm{Ala}$ variant displayed a significant decrease in potency (Figure 4D) after stimulation with DmelASTC (Table S2C,D). When we compared the amino acid sequences of these peptides, we observed a wellconserved disulfide bond and C-terminal SCF-amide residues 

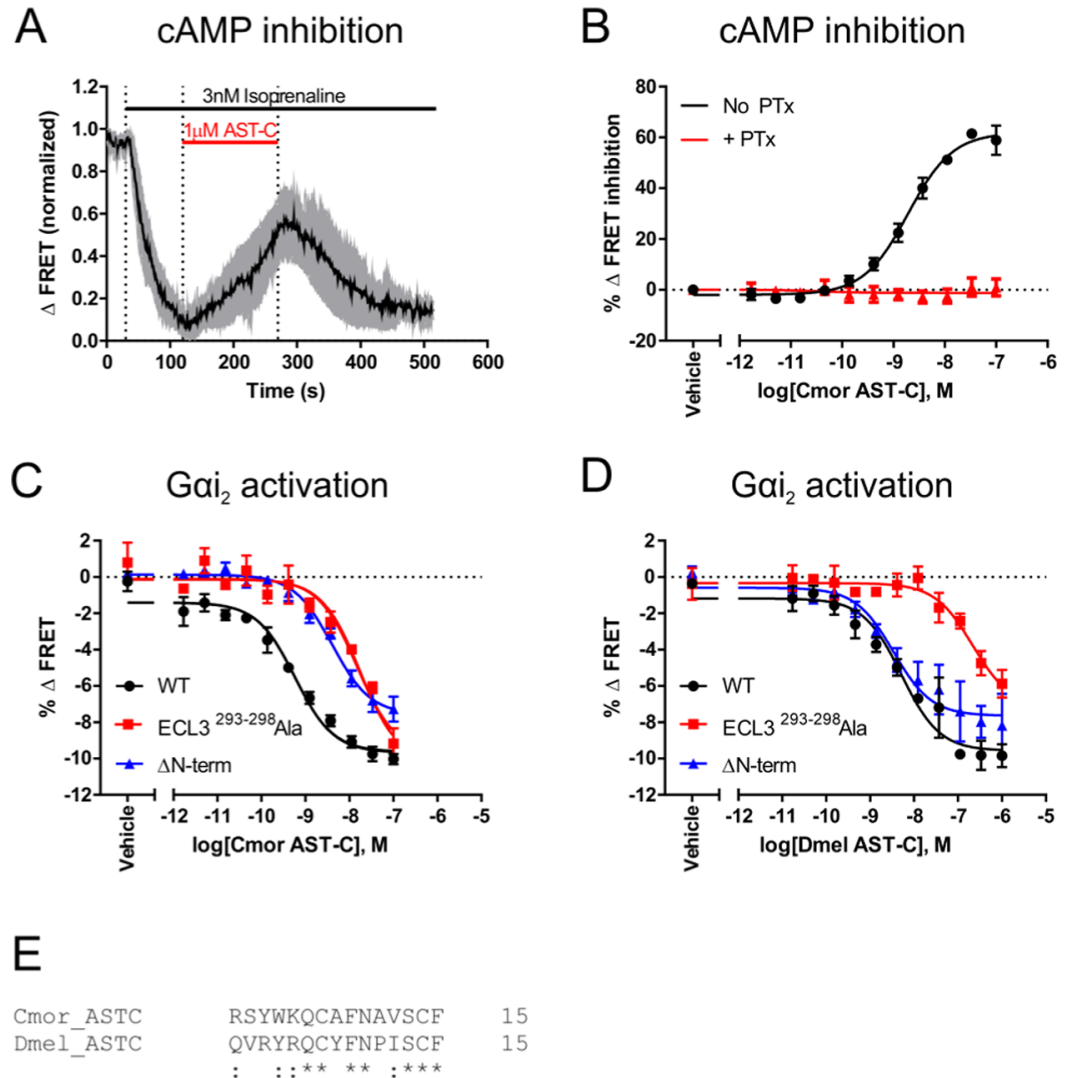

Figure 4. CamAlstRC and its mutants activate G $\alpha$ i2 distinctly. (A) Time-course FRET microscopy of AST-C-induced cAMP inhibition. HEK293 cells expressing Epac- ${ }^{\mathrm{H} 187}$ sensor with CamAlstRC were stimulated first with isoprenaline, and then AST-C simultaneously, followed by isoprenaline only. FRET trace represents the average of eight individual experiments from 3 experimental days. The error bar represents the standard deviation (SD). Data was normalized to the minimum and maximum values observed in the cumulative data. (B) Concentrationresponse relation of AST-C-mediated inhibition of Forskolin (Fsk)-induced cAMP production under PTx-treated (red) and -untreated (black) conditions in HEK293 cells expressing CmorAlstRC and Epac-S ${ }^{\mathrm{H} 187}$ sensor in 96-well plates. Concentration-response curve-fitting on GraphPad Prism resulted in a pEC50 value of $8.72 \pm 0.06$. Data points represent mean and the SEM from five independent experiments. (C and D) FRETbased measurement of ${\mathrm{G} \alpha \mathrm{i}_{2}}_{2}$ activation by CamAlstRC in a 96-well format. HEK293 cells expressing G $\alpha \mathrm{i}_{2}$ FRET sensor with CamAlstRC or its mutants were stimulated with different concentrations of (C) C. morosus AST-C (CmorAST-C) and (D) D. melanogaster AST-C (DmelASTC). A concentration-response curve was fitted using GraphPad Prism and the following pEC50 values were obtained with (C) CmorAST-C: WT $=9.24$ $\pm 0.08, \mathrm{ECL} 3^{293-298} \mathrm{Ala}=7.76 \pm 0.15$, and $\Delta \mathrm{N}$-term $=8.4 \pm 0.09$ and $(\mathrm{D})$ DmelASTC: $\mathrm{WT}=8.29 \pm 0.12$, ECL3 ${ }^{293-298} \mathrm{Ala}=6.67 \pm 0.21$, and $\Delta \mathrm{N}$-term $=8.47 \pm 0.18$. Data represents mean with the SEM from three to four independent plate reader experiments. (E) Sequence alignment of C. morosus and D. melanogaster AST-C peptides. The alignment was performed using the Clustal Omega tool. $(*)$ indicates fully conserved residues. (:) indicates residues scoring $>0.5$ in the Gonnet PAM 250 matrix.

in both peptides, while the similarity is low in the N-terminal residues (Figure 4E).

CmorAlstRC Recruits Human $\beta$-Arrestin2 Independently of Goi. We then sought to understand whether CmorAlstRC activation leads to further classical GPCR downstream events. Activated receptors are targeted by $\beta$ arrestins, which mediate receptor desensitization. To test $\beta$ arrestin recruitment to CmorAlstRC, we measured FRET in 96-well plates using HEK293 cells transfected with CmorAlstRC-EYFP and human $\beta$-arrestin2-ECFP. We observed an AST-C concentration-dependent increase in FRET with a pEC50 value of $6.82 \pm 0.05(\mathrm{SD})$. Also, the presence of PTx did not change the efficacy or the potency of AST-C notably $(\mathrm{pEC} 50=6.63 \pm 0.1$; Figure $5 \mathrm{~A})$.

To investigate the kinetics of $\beta$-arrestin recruitment, we performed FRET microscopy in single cells expressing CmorAlstRC-EYFP and $\beta$-arrestin2-ECFP. We repeatedly superfused cells with $10 \mu \mathrm{M}$ AST-C (Figure 5B) and observed a slow increase in FRET in the first stimulation, compared to that of the second one (Figure 5B,C). However, the kinetics of the FRET decrease upon ligand wash-out was comparable for both stimulations (Figure 5D).

These results suggest that activated CmorAlstRC interacts with $\beta$-arrestin 2 in a $\mathrm{Gi}$ protein-independent manner.

CmorAlstRC Induces ERK Phosphorylation in a PTXDependent Manner. MAPK (mitogen-activated protein kinase)-ERK (extracellular signal-regulated kinase) pathway activation is a well-established pathway for several GPCRs. ${ }^{49}$ We tested whether CmorAlstRC activation in HEK293 cells can induce this pathway. For this purpose, we used the FRETbased EKAR (extracellular signal-regulated kinase activity reporter) sensor that reports ERK phosphorylation as an increase in the FRET signal. This sensor consists of a phosphorylation domain of $\mathrm{Cdc} 25 \mathrm{C}$ that is targeted by MAPK and a phosphobinding WW domain that is sandwiched by donor and acceptor fluorophores. ${ }^{39}$ We investigated this pathway in two cellular compartments using cytoplasm- and nucleus-localized EKAR sensors. Using cells in 96-well plates transfected with CmorAlstRC with either cytoplasmic or nuclear EKAR, we measured time-dependent changes in FRET 
A $\beta$-arrestin2 recruitment

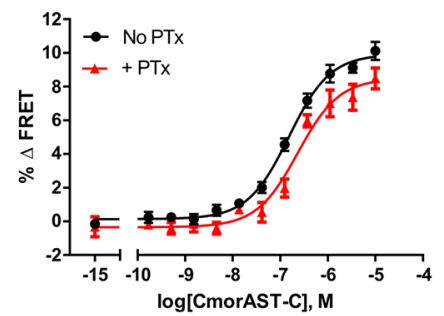

C

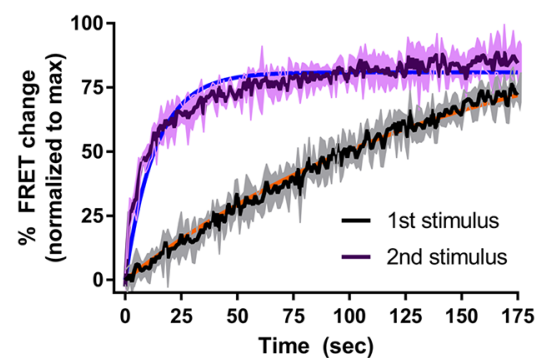

E

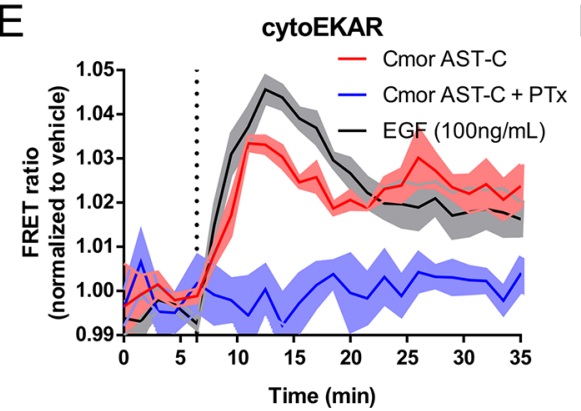

B $\beta$-arrestin2 recruitment kinetics

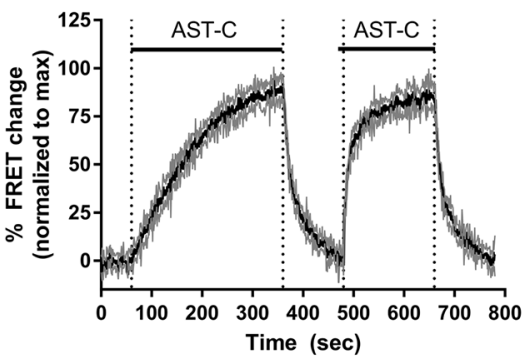

D $\quad \beta$-arrestin2 dissociation

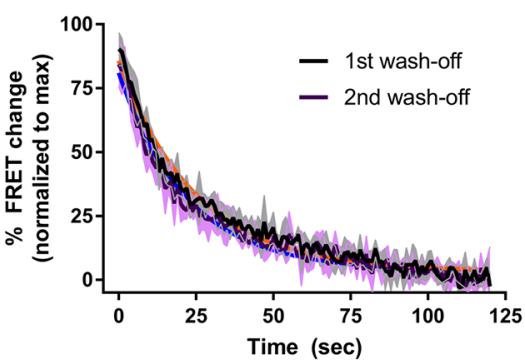

$\mathrm{F}$
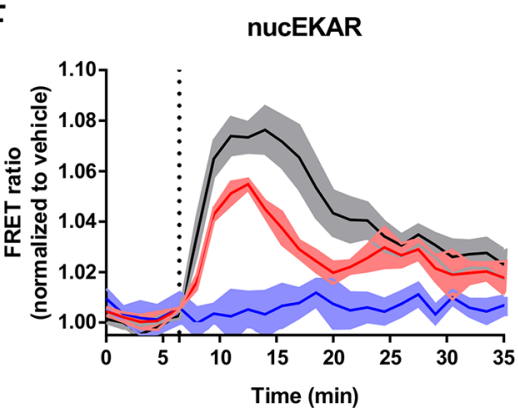

Figure 5. CamAlstRC activation recruits $\beta$-arrestin2 to the receptor and stimulates ERK phosphorylation. (A) FRET-based measurement of $\beta$ arrestin2-ECFP recruitment to CamAlstRC-EYFP under PTX-treated (red) and -untreated (black) conditions measured in a 96-well format in HEK293 cells. The dose-response curve-fitting resulted in pEC50 values as no PTx $=6.81 \pm 0.05(\mathrm{SD})$ and $+\mathrm{PTx}=6.63 \pm 0.1$. Each data point represents the average with the SEM of three to six independent plate reader experiments. (B) Cells were repeatedly superfused/washed with AST$\mathrm{C} /$ buffer to observe the association/dissociation kinetics of $\beta$-arrestin2-ECFP recruitment to CamAlstRC-EYFP using FRET microscopy. (C) Association and (D) dissociation kinetics data was calculated using the data derived from (B). A monoexponential association/decay function was fit to calculate the tau values for $(\mathrm{C})$ association: first stimulus (blue) $=155.3 \mathrm{~s}[150-161 \mathrm{CI}]$ and second stimulus (orange) $=13.5 \mathrm{~s}[12.8-14.3$ $\mathrm{CI}]$. The tau values for (D) dissociation were first wash-off (blue) $=17.2 \mathrm{~s}[23.5-26.4 \mathrm{CI}]$ and second wash-off $($ orange $)=15.3 \mathrm{~s}$ [20.6-23.5 CI]. The FRET trace represents the average with an SD of five different experiments from 3 experimental days. (E and F) 96-well format FRET measurement of ERK phosphorylation by AST-C. Cells expressing (E) cytosolic EKAR or (F) nuclear EKAR sensor with CamAlstRC were treated with AST-C at the time point indicated by the dotted line. Epidermal growth factor (EGF) stimulation (black) was used as a positive control. FRET traces represent the average with SEM of four to five independent plate reader experiments.

upon stimulation with AST-C and epidermal growth factor (EGF). Here, EGF served as a positive control, as it activates the EGF receptor, which in turn stimulates ERK phosphorylation. $^{39}$ Both EGF and AST-C increased cytosolic and nuclear FRET signals within a minute, and the signal peaked within $5 \mathrm{~min}$ after the stimulus (Figure 5E,F). In AST-C stimulated cells we observed a persistent cytosolic FRET signal, while it increased only transiently in the nucleus. When we pretreated the cells with PTx, we did not observe any ERK phosphorylation by AST-C in either compartment (Figure 5E,F). Together, these results suggest that CmorAlstRC activation can induce ERK phosphorylation in a PTxdependent manner both in cytosolic and in nuclear compartments of HEK293 cells.

Evolutionary Conservation of G $\alpha \mathrm{i}$, Arrestin, and GRK Proteins. Since we observed that human $\mathrm{G} \alpha \mathrm{i}_{2}$ and $\beta$-arrestin could couple to phasmid GPCR, we sought to investigate the conservation of these proteins within various species. To do this, we first searched the Transcript Shotgun Assembly (TSA) data of $C$. morosus, using human $\mathrm{G} \alpha \mathrm{i}_{2}, \beta$-arrestin2, and GRK2 as queries. We identified one transcript corresponding to a Cmor G $\alpha$ i, two corresponding to arrestin, and one corresponding to GRK. Partial G $\alpha$ i protein sequence showed conserved sequences with $G$ proteins from several species on the putative receptor binding site (Table S3A) and G $\beta \gamma$ binding site (Table S3B). Using the C. morosus G $\alpha$ i transcript in BLASTx as a query, we obtained several insect G $\alpha \mathrm{i}$ and G $\alpha \mathrm{i}$ like protein sequences with over $90 \%$ similarity. Among these, Zootermopsis nevadensis (Znev) G $\alpha$ i displayed the highest (97.5\%) sequence identity. Next, we performed a phylogenetic analysis between the $C$. morosus $\mathrm{G} \alpha \mathrm{i}$-like protein and other $\mathrm{G} \alpha$ subunits from the $Z$. nevadensis genome. The identified $C$. morosus transcript belongs to the same branch as $Z$. nevadensis $\mathrm{G} \alpha \mathrm{i}$ and is distant from other $\mathrm{G} \alpha$ subunits, suggesting that it 
A

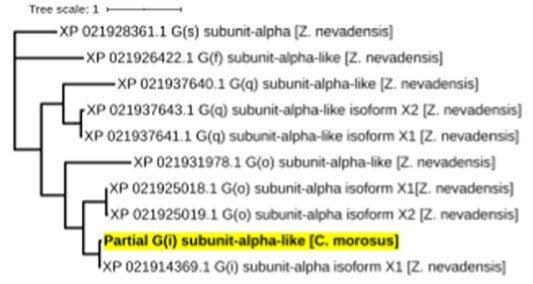

C

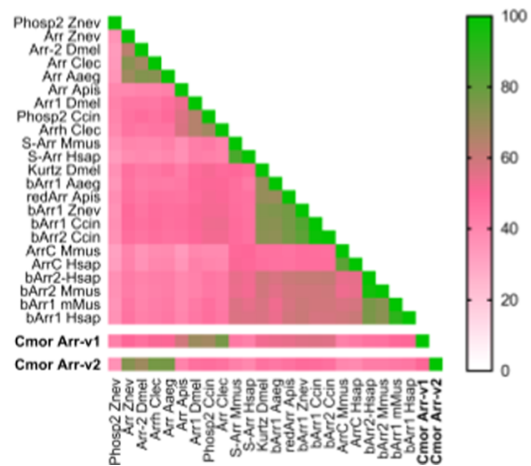

$\mathrm{B}$

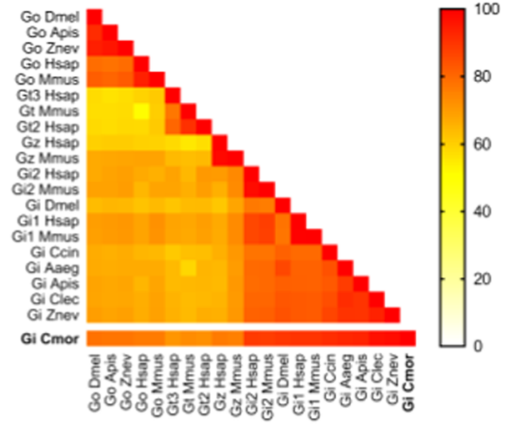

D

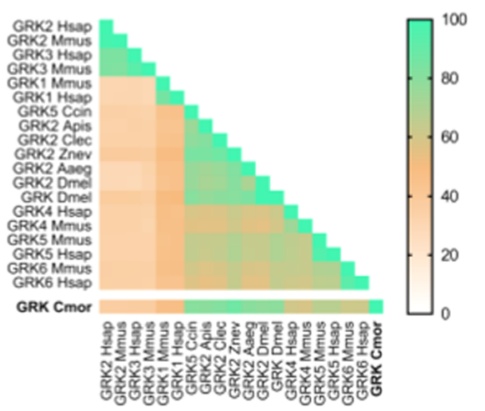

Figure 6. Adult C. morosus transcriptome analysis reveals species-specific G $\alpha \mathrm{i}$, arrestins, and GRK. (A) Protein BLAST-derived phylogenetic tree of C. morosus $\mathrm{G} \alpha \mathrm{i}$ subunit inferred against $Z$. nevadensis genome. Multiple alignments were automatically generated by BLASTp and the tree was constructed via the neighbor-joining tree method using the NGPhylogeny tool. Codes starting with XP represent the protein accession number on NCBI genes. (B, C, and D) Heat-map matrix representation of protein sequence identity comparison $(100=$ complete sequence homology). A cross-comparison of G $\alpha \mathrm{i}$ (B), arrestins (C), and GRK (D) proteins from multiple species (Cmor: C. morosus, Hsap: Homo sapiens, Mmus: Mus musculus, Dmel: D. melanogaster, Apis: Acyrthosiphom pisum, Znev: Z. nevadensis, Aaeg: Aedes aegypti, Clec: Cimex lectularis, and Ccin: Cephus cinctus) was performed using the Sequence Identity and Similarity tool.

corresponds to a $\mathrm{G} \alpha \mathrm{i}$-coding transcript (Figure $6 \mathrm{~A}$ ). When we compared the sequence identity of the C. morosus Goi-like protein with representative $\mathrm{G} \alpha \mathrm{i} / \mathrm{o} / \mathrm{z} / \mathrm{t}$ subunits from vertebrate and insect species, we obtained the highest similarity values from $\mathrm{G} \alpha \mathrm{i}$ subunits, while the lowest similarities were observed for $\mathrm{G} \alpha$ t subunits (Figures 6B and S3A). Of note, the sequence similarity between the $C$. morosus partial Goi-like protein and human $\mathrm{G} \alpha \mathrm{i}_{2}$, which is the subtype we used in our functional assays, was found to be $\sim 88.6 \%$. Moreover, these two proteins displayed an exactly identical C-terminal domain (Table S3C), which is one of the determinants of Gi coupling selectivity. ${ }^{50}$

Using the arrestin protein sequences from the same species as above, we performed another set of multiple alignments, including the identified arrestin transcripts from C. morosus. Compared to the $\mathrm{G} \alpha \mathrm{i}, \mathrm{C}$. morosus arrestins showed a lower sequence identity. Human $\beta$-arrestin 2 was only $46 \%$ identical with C. morosus Arrestin 1 and $42.5 \%$ with Arrestin2 (Table S3D). On the other hand, both C. morosus arrestin transcripts showed maximum identity with $A$. aegypti, C. lectularis, and D. melanogaster arrestins, while the lowest identity was observed with phosphorestins, S-arrestins, and arrestin-Cs (Figures 6C and $\mathrm{S} 3 \mathrm{~B})$.

The longest transcript encoding a Cmor GRK-like protein showed more than $80 \%$ sequence identity with $A$. aegypti, $C$. lectularis, and Z. nevadensis GRKs. From the human GRKs, GRK5 (67.2\%) appeared to be more similar than GRK2
(36.5\%) and GRK3 (37.2\%) to the identified C. morosus GRKlike (Figures 6D and S3C).

Together, the phylogenetic analyses of C. morosus GPCRassociated signaling proteins showed a divergent similar to their human homologues. While C. morosus G $\alpha$ i was highly conserved, arrestin and GRK from representative insect species appeared to be less related to their human homologues.

\section{DISCUSSION}

In this work, we characterized an AlstRC from the stick insect C. morosus by assessing the downstream signaling events and receptor-effector interactions.

Using FRET microscopy techniques, we detected that CmorAlstRC couples to the human $\mathrm{G} \alpha \mathrm{i}_{2}$ even with nanomolar concentrations of AST-C. At saturating concentrations, this coupling occurs with $\sim 200 \mathrm{~ms}$ apparent kinetics, which is in the same kinetic range that was measured for a number of human GPCR-G protein interactions. ${ }^{51}$ This coupling led to human $\mathrm{G} \alpha \mathrm{i}_{2}$ activation, with a matching potency for receptor$\mathrm{G}$ protein interaction. With a cAMP-detecting FRET sensor and PTx, we were able to corroborate the specific $\mathrm{G} \alpha$ i protein activation by CmorAlstRC. As expected, phylogenetic analysis of $\mathrm{G} \alpha \mathrm{i}$ subunits from vertebrates and insects of different orders exhibited highly conserved patterns of a G $\alpha$ i subunit, explaining how CmorAlstRC could couple to and activate the vertebrate $\mathrm{Gi}$ proteins. 
Our previous observations suggested that both receptor Nterminus and the ${ }^{293}{ }^{2}$ IFTTP $^{298}$ motif on the ECL3 are crucial for AST-C binding. ${ }^{37}$ First, we confirmed that the membrane localization of these mutants is not impaired. We observed that the alanine conversion of the IFTTP motif or the deletion of the N-terminus of CmorAlstRC decreased the potency of the agonist-induced $\mathrm{G} \alpha \mathrm{i}_{2}$ activation. These results confirm the importance of both motifs for CmorAlstRC-mediated $\mathrm{G} \alpha \mathrm{i}_{2}$ signaling. A decreased efficacy on the $\Delta \mathrm{N}$-term mutant might explain how this domain supports the correct orientation of the ligand on the receptor to achieve maximal receptor activation.

In comparison to the Cmor peptide, a structurally distinct form of AST-C from D. melanogaster displayed lower potency in the $\mathrm{G} \alpha \mathrm{i}_{2}$ activation assay. This decrease in EC50 might be due to the different amino acid compositions of these peptides. Surprisingly, when we tested Dmel AST-C on the G protein assay, we observed that this peptide exhibited the same EC50 on the $\Delta \mathrm{N}$-term receptor variant but a large decrease in potency and efficacy on the ECL $3^{293-298} \mathrm{Ala}$ mutant. Therefore, it is possible that the $\mathrm{N}$-terminus of the receptor forms a different interaction with Dmel peptide compared to the Cmor peptide, which causes the decreased potency in the $\mathrm{G} \alpha \mathrm{i}_{2}$ activation. On the other hand, the large potency decrease observed on the ECL3 mutant explains that this domain is crucial for CmorAlstRC-mediated G $\alpha \mathrm{i}_{2}$ signaling. Additionally, this domain may form a hinge point for the other constituents (N-term and ECL2) of the binding pocket, even with the alanine substitutions.

Using FRET, we observed that CmorAlstRC recruits human $\beta$-arrestin 2 independently of Gi protein coupling. However, the kinetics of this association is approximately 10 times slower compared to the human $\beta_{2} \mathrm{AR}$ coupling to $\beta$-arrestin $2 .{ }^{43}$ This slow kinetics of the arrestin coupling to CmorAlstRC may be due to the low sequence conservation between vertebrate and insect arrestins, as shown by our phylogenetic analyses. On the other hand, repeated stimulus with AST-C increased the speed of $\beta$-arrestin 2 recruitment to CmorAlstRC. A similar acceleration in arrestin coupling by repeated agonist stimulus was also observed for $\beta_{2} \mathrm{AR}^{43}$ In the case of $\beta_{2} \mathrm{AR}$, this increase is a result of the receptor phosphorylation by the prestimuli. It must be further investigated whether insect receptors interact with the arrestins in a phosphorylation-dependent manner.

Lastly, CmorAlstRC induces a transient, PTx-sensitive MAPK-ERK pathway activation in the cytosol and nucleus. PTx-sensitivity of the ERK activation by CmorAlstRC is in line with a previous observation suggesting the MAPK-ERK pathway activation by GPCRs to be G protein-dependent, at least in HEK293 cells. ${ }^{52}$ Yet, it should be considered that this process may be receptor- and cell type-specific.

Altogether, this work delineates the pharmacological features of the C. morosus AST-C with its cognate GPCR by measuring multiple signaling pathways and protein-protein interactions. An important aspect of our work is probing the use of several FRET-based tools to characterize $G$ protein subtype and pathway specificity, as well as interactions with downstream effectors, in pharmacological and kinetic aspects for an insect GPCR. Therefore, we believe that our work here provides a selection of assays with great potential to deorphanize and characterize insect GPCRs and their associated signaling pathways. Moreover, FRET-based biosensors have been used in vivo in model animals, such as D. melanogaster ${ }^{14,53}$ and Caenorhabditis elegans. ${ }^{54}$ Recently, a number of novel biosensors that report direct GPCR activation were shown to be functional in insects and allowed for real-time imaging of receptor dynamics, as well as neurotransmitter-mediated signaling in insects in vivo. ${ }^{55,56}$ In light of these emerging technologies, the biosensors that we describe here may also be suitable for dissecting the spatio-temporal dynamics of signaling in insects in vivo.

\section{ASSOCIATED CONTENT}

\section{SI Supporting Information}

The Supporting Information is available free of charge at https://pubs.acs.org/doi/10.1021/acsomega.0c03382.

Control experiments probing CmorAST-C specificity of CmorAlstRC activation in HEK293 cells (Figure S1); confocal microscopy assessment of the expression levels and subcellular localization of CmorAlstRC mutants (Figure S2); evolutionary relationship of C. morosus $\mathrm{G} \alpha \mathrm{i}$, arrestin, and GRK transcripts with mammalian and insect species (Figure S3); sequence identity of allatostatin-C from C. morosus and other insect species (Table S1); statistical analysis of the $\log$ EC50 and $E_{\max }$ values obtained from Figure 3B,C (Table S2); and sequence alignment of the conserved domains of $C$. morosus G $\alpha \mathrm{i}$-, arrestin-, and GRK-like transcripts with multiple species (Table S3) (PDF)

\section{AUTHOR INFORMATION}

\section{Corresponding Author}

Necla Birgül-Iyison - Department of Molecular Biology and Genetics, Faculty of Arts and Sciences, Bogazici University, Istanbul 34342, Turkey; (1) orcid.org/0000-0003-35113139; Email: birgul@boun.edu.tr

\section{Authors}

Ali Işbilir - Department of Molecular Biology and Genetics, Faculty of Arts and Sciences, Bogazici University, Istanbul 34342, Turkey; Max Delbrück Center for Molecular Medicine in the Helmholtz Association, Berlin 13125, Germany; Institute of Pharmacology and Toxicology, University of Würzburg, Würzburg 97078, Germany

Burcin Duan Sahbaz - Department of Molecular Biology and Genetics, Faculty of Arts and Sciences, Bogazici University, Istanbul 34342, Turkey

Gunes Tuncgenc - Department of Molecular Biology and Genetics, Faculty of Arts and Sciences, Bogazici University, Istanbul 34342, Turkey

Moritz Bünemann - Department of Pharmacology and Clinical Pharmacy, Philipps-University, Marburg 35043, Germany

Martin J. Lohse - Max Delbrück Center for Molecular Medicine in the Helmholtz Association, Berlin 13125, Germany; Institute of Pharmacology and Toxicology, University of Würzburg, Würzburg 97078, Germany; ISAR Bioscience Institute, Planegg/Munich 82152, Germany

Complete contact information is available at:

https://pubs.acs.org/10.1021/acsomega.0c03382

\section{Notes}

The authors declare no competing financial interest.

\section{ACKNOWLEDGMENTS}

This work was financially supported by European Cooperation in Science and Technology (COST) Action CM1207 GPCR- 
Ligand Interactions, Structures, and Transmembrane Signaling: A European Research Network (GLISTEN) and CA18133 European Research Network on Signal Transduction (ERNEST), Boğaziçi University Research Projects (Project code: 5043), and The Scientific and Technological Research Council of Turkey (Project code: 113Z079). The funding facilities did not participate in the design of the study, collection, analysis and interpretation of data, or in the writing of the manuscript. We would like to thank Dr. Isabella Maiellaro (University of Nottingham, United Kingdom) for critically reading the manuscript.

\section{REFERENCES}

(1) Schoofs, L.; De Loof, A.; Van Hiel, M. B. Neuropeptides as Regulators of Behavior in Insects. Annu. Rev. Entomol. 2017, 62, 3552.

(2) Caers, J.; Verlinden, H.; Zels, S.; Vandersmissen, H. P.; Vuerinckx, K.; Schoofs, L. More than Two Decades of Research on Insect Neuropeptide GPCRs: An Overview. Front. Endocrinol. 2012, $3,151$.

(3) Schöneberg, T.; Hofreiter, M.; Schulz, A.; Römpler, H. Learning from the Past: Evolution of GPCR Functions. Trends Pharmacol. Sci. 2007, 28, 117-121.

(4) Richards, S.; Gibbs, R. A.; Gerardo, N. M.; Moran, N.; Nakabachi, A.; Stern, D.; Tagu, D.; Wilson, A. C. C.; Muzny, D.; Kovar, C.; Cree, A.; Chacko, J.; Chandrabose, M. N.; Dao, M. D.; Dinh, H. H.; Gabisi, R. A.; Hines, S.; Hume, J.; Jhangian, S. N.; Joshi, V.; Lewis, L. R.; Liu, Y. S.; Lopez, J.; Morgan, M. B.; Nguyen, N. B.; Okwuonu, G. O.; Ruiz, S. J.; Santibanez, J.; Wright, R. A.; Fowler, G. R.; Hitchens, M. E.; Lozado, R. J.; Moen, C.; Steffen, D.; Warren, J. T.; Zhang, J.; Nazareth, L. V.; Chavez, D.; Davis, C.; Lee, S. L.; Patel, B. M.; Pu, L. L.; Bell, S. N.; Johnson, A. J.; Vattathil, S.; Williams, R. L.; Shigenobu, S.; Dang, P. M.; Morioka, M.; Fukatsu, T.; Kudo, T.; Miyagishima, S. Y.; Jiang, H.; Worley, K. C.; Legeai, F.; Gauthier, J. P.; Collin, O.; Zhang, L.; Chen, H. C.; Ermolaeva, O.; Hlavina, W.; Kapustin, Y.; Kiryutin, B.; Kitts, P.; Maglott, D.; Murphy, T.; Pruitt, K.; Sapojnikov, V.; Souvorov, A.; Thibaud-Nissen, F.; Câmara, F.; Guigó, R.; Stanke, M.; Solovyev, V.; Kosarev, P.; Gilbert, D.; Gabaldón, T.; Huerta-Cepas, J.; Marcet-Houben, M.; Pignatelli, M.; Moya, A.; Rispe, C.; Ollivier, M.; Quesneville, H.; Permal, E.; Llorens, C.; Futami, R.; Hedges, D.; Robertson, H. M.; Alioto, T.; Mariotti, M.; Nikoh, N.; McCutcheon, J. P.; Burke, G.; Kamins, A.; Latorre, A.; Ashton, P.; Calevro, F.; Charles, H.; Colella, S.; Douglas, A. E.; Jander, G.; Jones, D. H.; Febvay, G.; Kamphuis, L. G.; Kushlan, P. F.; Macdonald, S.; Ramsey, J.; Schwartz, J.; Seah, S.; Thomas, G.; Vellozo, A.; Cass, B.; Degnan, P.; Hurwitz, B.; Leonardo, T.; Koga, R.; Altincicek, B.; Anselme, C.; Atamian, H.; Barribeau, S. M.; De Vos, M.; Duncan, E. J.; Evans, J.; Ghanim, M.; Heddi, A.; Kaloshian, I.; Vincent-Monegat, C.; Parker, B. J.; Pérez-Brocal, V.; Rahbé, Y.; Spragg, C. J.; Tamames, J.; Tamarit, D.; Tamborindeguy, C.; Vilcinskas, A.; Bickel, R. D.; Brisson, J. A.; Butts, T.; Chang, C. C.; Christiaens, O.; Davis, G. K.; Duncan, E.; Ferrier, D.; Iga, M.; Janssen, R.; Lu, H. L.; McGregor, A.; Miura, T.; Smagghe, G.; Smith, J.; Van Der Zee, M.; Velarde, R.; Wilson, M.; Dearden, P.; Edwards, O. R.; Gordon, K.; Hilgarth, R. S.; Rider, S. D.; Srinivasan, D.; Walsh, T. K.; Ishikawa, A.; Jaubert-Possamai, S.; Fenton, B.; Huang, W.; Rizk, G.; Lavenier, D.; Nicolas, J.; Smadja, C.; Zhou, J. J.; Vieira, F. G.; He, X. L.; Liu, R.; Rozas, J.; Field, L. M.; Campbell, P.; Carolan, J. C.; Fitzroy, C. I. J.; Reardon, K. T.; Reeck, G. R.; Singh, K.; Wilkinson, T. L.; Huybrechts, J.; Abdel-Latief, M.; Robichon, A.; Veenstra, J. A.; Hauser, F.; Cazzamali, G.; Schneider, M.; Williamson, M.; Stafflinger, E.; Hansen, K. K.; Grimmelikhuijzen, C. J. P.; Price, D. R. G.; Caillaud, M.; Van Fleet, E.; Ren, Q.; Gatehouse, J. A.; Brault, V.; Monsion, B.; Diaz, J.; Hunnicutt, L.; Ju, H. J.; Pechuan, X.; Aguilar, J.; Cortés, T.; Ortiz-Rivas, B.; Martínez-Torres, D.; Dombrovsky, A.; Dale, R. P.; Davies, T. G. E.; Williamson, M. S.; Jones, A.; Sattelle, D.; Williamson, S.; Wolstenholme, A.; Cottret, L.; Sagot, M. F.; Heckel,
D. G.; Hunter, W. Genome Sequence of the Pea Aphid Acyrthosiphon Pisum. PLoS Biol. 2010, 8, No. e1000313.

(5) Grbić, M.; Van Leeuwen, T.; Clark, R. M.; Rombauts, S.; Rouzé, P.; Grbić, V.; Osborne, E. J.; Dermauw, W.; Ngoc, P. C. T.; Ortego, F.; Hernández-Crespo, P.; Diaz, I.; Martinez, M.; Navajas, M.; Sucena, É.; Magalhães, S.; Nagy, L.; Pace, R. M.; Djuranović, S.; Smagghe, G.; Iga, M.; Christiaens, O.; Veenstra, J. A.; Ewer, J.; Villalobos, R. M.; Hutter, J. L.; Hudson, S. D.; Velez, M.; Yi, S. V.; Zeng, J.; Pires-Da Silva, A.; Roch, F.; Cazaux, M.; Navarro, M.; Zhurov, V.; Acevedo, G.; Bjelica, A.; Fawcett, J. A.; Bonnet, E.; Martens, C.; Baele, G.; Wissler, L.; Sanchez-Rodriguez, A.; Tirry, L.; Blais, C.; Demeestere, K.; Henz, S. R.; Gregory, T. R.; Mathieu, J.; Verdon, L.; Farinelli, L.; Schmutz, J.; Lindquist, E.; Feyereisen, R.; Van De Peer, Y. The Genome of Tetranychus Urticae Reveals Herbivorous Pest Adaptations. Nature 2011, 479, 487-492.

(6) Xu, G.; Gu, G. X.; Teng, Z. W.; Wu, S. F.; Huang, J.; Song, Q. S.; Ye, G. Y.; Fang, Q. Identification and Expression Profiles of Neuropeptides and Their G Protein-Coupled Receptors in the Rice Stem Borer Chilo Suppressalis. Sci. Rep. 2016, 6, No. 28976.

(7) Tanaka, Y.; Suetsugu, Y.; Yamamoto, K.; Noda, H.; Shinoda, T. Transcriptome Analysis of Neuropeptides and G-Protein Coupled Receptors (GPCRs) for Neuropeptides in the Brown Planthopper Nilaparvata Lugens. Peptides 2014, 53, 125-133.

(8) Ons, S.; Richter, F.; Urlaub, H.; Pomar, R. R. The Neuropeptidome of Rhodnius Prolixus Brain. Proteomics 2009, 9, 788-792.

(9) Hui, L.; Xiang, F.; Zhang, Y.; Li, L. Mass Spectrometric Elucidation of the Neuropeptidome of a Crustacean Neuroendocrine Organ. Peptides 2012, 36, 230-239.

(10) Benredjem, B.; Gallion, J.; Pelletier, D.; Dallaire, P.; Charbonneau, J.; Cawkill, D.; Nagi, K.; Gosink, M.; Lukasheva, V.; Jenkinson, S.; Ren, Y.; Somps, C.; Murat, B.; Van Der Westhuizen, E.; Le Gouill, C.; Lichtarge, O.; Schmidt, A.; Bouvier, M.; Pineyro, G. Exploring Use of Unsupervised Clustering to Associate Signaling Profiles of GPCR Ligands to Clinical Response. Nat. Commun. 2019, 10, No. 4075.

(11) Olsen, R. H. J.; DiBerto, J. F.; English, J. G.; Glaudin, A. M.; Krumm, B. E.; Slocum, S. T.; Che, T.; Gavin, A. C.; McCorvy, J. D.; Roth, B. L.; Strachan, R. T. TRUPATH, an Open-Source Biosensor Platform for Interrogating the GPCR Transducerome. Nat. Chem. Biol. 2020, 1-9.

(12) Lohse, M. J.; Hein, P.; Hoffmann, C.; Nikolaev, V. O.; Vilardaga, J.-P.; Bünemann, M. Kinetics of G-Protein-Coupled Receptor Signals in Intact Cells. Br. J. Pharmacol. 2009, 153, S125S132.

(13) Foster, S. R.; Hauser, A. S.; Vedel, L.; Strachan, R. T.; Huang, X. P.; Gavin, A. C.; Shah, S. D.; Nayak, A. P.; Haugaard-Kedström, L. M.; Penn, R. B.; Roth, B. L.; Bräuner-Osborne, H.; Gloriam, D. E. Discovery of Human Signaling Systems: Pairing Peptides to G Protein-Coupled Receptors. Cell 2019, 179, 895-908.

(14) Maiellaro, I.; Lohse, M. J.; Kittel, R. J.; Calebiro, D. CAMP Signals in Drosophila Motor Neurons Are Confined to Single Synaptic Boutons. Cell Rep. 2016, 17, 1238-1246.

(15) Himmelreich, S.; Masuho, I.; Berry, J. A.; MacMullen, C.; Skamangas, N. K.; Martemyanov, K. A.; Davis, R. L. Dopamine Receptor DAMB Signals via Gq to Mediate Forgetting in Drosophila. Cell Rep. 2017, 21, 2074-2081.

(16) Lismont, E.; Verbakel, L.; Vogel, E.; Corbisier, J.; Degroot, G. N.; Verdonck, R.; Verlinden, H.; Marchal, E.; Springael, J. Y.; Vanden Broeck, J. Can BRET-Based Biosensors Be Used to Characterize GProtein Mediated Signaling Pathways of an Insect GPCR, the Schistocerca Gregaria CRF-Related Diuretic Hormone Receptor? Insect Biochem. Mol. Biol. 2020, 122, No. 103392.

(17) Granger, N. A.; Janzen, W. P. Inhibition of Manduca sexta, Corpora allata in Vitro by a Cerebral Allatostatic Neuropeptide. Mol. Cell. Endocrinol. 1987, 49, 237-248.

(18) Woodhead, A. P.; Stay, B.; Seidel, S. L.; Khan, M. A.; Tobe, S. S. Primary Structure of Four Allatostatins: Neuropeptide Inhibitors of 
Juvenile Hormone Synthesis. Proc. Natl. Acad. Sci. U.S.A. 1989, 86, 5997-6001.

(19) Kramer, S. J.; Toschi, A.; Miller, C. A.; Kataoka, H.; Quistad, G. B.; Li, J. P.; Carney, R. L.; Schooley, D. A. Identification of an Allatostatin from the Tobacco Hornworm Manduca sexta. Proc. Natl. Acad. Sci. U.S.A. 1991, 88, 9458-9462.

(20) Li, Y.; Hernandez-Martinez, S.; Fernandez, F.; Mayoral, J. G.; Topalis, P.; Priestap, H.; Perez, M.; Navare, A.; Noriega, F. G. Biochemical, Molecular, and Functional Characterization of PISCFAllatostatin, a Regulator of Juvenile Hormone Biosynthesis in the Mosquito Aedes aegypti. J. Biol. Chem. 2006, 281, 34048-34055.

(21) Price, M. D.; Merte, J.; Nichols, R.; Koladich, P. M.; Tobe, S. S.; Bendena, W. G. Drosophila melanogaster Flatline Encodes a Myotropin Orthologue to Manduca sexta Allatostatin. Peptides 2002, 23, 787-794.

(22) Bachtel, N. D.; Hovsepian, G. A.; Nixon, D. F.; Eleftherianos, I. Allatostatin C Modulates Nociception and Immunity in Drosophila. Sci. Rep. 2018, 8, No. 7501.

(23) Díaz, M. M.; Schlichting, M.; Abruzzi, K. C.; Long, X.; Rosbash, M. Allatostatin-C/AstC-R2 Is a Novel Pathway to Modulate the Circadian Activity Pattern in Drosophila. Curr. Biol. 2019, 29, 13-22.

(24) Down, R. E.; Matthews, H. J.; Audsley, N. Effects of Manduca sexta Allatostatin and an Analog on the Pea Aphid Acyrthosiphon Pisum (Hemiptera: Aphididae) and Degradation by Enzymes from the Aphid Gut. Peptides 2010, 31, 489-497.

(25) Matthews, H. J.; Down, R. E.; Audsley, N. Effects of Manduca sexta Allatostatin and an Analogue on the Peach-Potato Aphid Myzus Persicae (Hemiptera: Aphididae) and Degradation by Enzymes in the Aphid Gut. Arch. Insect Biochem. Physiol. 2010, 75, 139-157.

(26) Kreienkamp, H. J.; Akgün, E.; Baumeister, H.; Meyerhof, W.; Richter, D. Somatostatin Receptor Subtype 1 Modulates Basal Inhibition of Growth Hormone Release in Somatotrophs. FEBS Lett. 1999, 462, 464-466.

(27) Stengel, A.; Goebel, M.; Wang, L.; Rivier, J.; Kobelt, P.; Monnikes, H.; Tache, Y. Selective Central Activation of Somatostatin Receptor 2 Increases Food Intake, Grooming Behavior and Rectal Temperature in Rats. J. Physiol. Pharmacol. 2010, 61, 399-407.

(28) Patel, Y. C. Somatostatin and Its Receptor Family. Front. Neuroendocrinol. 1999, 20, 157-198.

(29) Dürr, V.; König, Y.; Kittmann, R. The Antennal Motor System of the Stick Insect C. morosus: Anatomy and Antennal Movement Pattern during Walking. J. Comp. Physiol., A 2001, 187, 131-144.

(30) Westmark, S.; Oliveira, E. E.; Schmidt, J. Pharmacological Analysis of Tonic Activity in Motoneurons during Stick Insect Walking. J. Neurophysiol. 2009, 102, 1049-1061.

(31) Oliveira, E. E.; Pippow, A.; Salgado, V. L.; Büschges, A.; Schmidt, J.; Kloppenburg, P. Cholinergic Currents in Leg Motoneurons of C. morosus. J. Neurophysiol. 2010, 103, 2770-2782.

(32) Miksys, S.; Lange, A. B.; Orchard, I.; Wong, V. Localization and Neurohemal Release of FMRFamide-Related Peptides in the Stick Insect Carausius morosus. Peptides 1997, 18, 27-40.

(33) Marco, H. G.; Katali, O. K. H.; Gäde, G. Influence of Aminergic and Peptidergic Substances on Heart Beat Frequency in the Stick Insect C. morosus (Insecta, Phasmatodea). Arch. Insect Biochem. Physiol. 2018, 98, No. e21469.

(34) Lorenz, M. W.; Kellner, R.; Hoffmann, K. H.; Gäde, G. Identification of Multiple Peptides Homologous to Cockroach and Cricket Allatostatins in the Stick Insect Carausius morosus. Insect Biochem. Mol. Biol. 2000, 30, 711-718.

(35) Liessem, S.; Ragionieri, L.; Neupert, S.; Büschges, A.; Predel, R. Transcriptomic and Neuropeptidomic Analysis of the Stick Insect, Carausius morosus. J. Proteome Res. 2018, 17, 2192-2204.

(36) Şahbaz, B.; Birgül İyison, N. Prediction and Expression Analysis of G Protein-Coupled Receptors in the Laboratory Stick Insect, Carausius morosus. Turk. J. Biol. 2019, 43, 77-88.

(37) Şahbaz, B. D.; Sezerman, O. U.; Torun, H.; Iyison, N. B. Ligand Binding Pocket of a Novel Allatostatin Receptor Type C of Stick Insect, Carausius morosus. Sci. Rep. 2017, 7, No. 41266.
(38) Van Unen, J.; Stumpf, A. D.; Schmid, B.; Reinhard, N. R.; Hordijk, P. L.; Hoffmann, C.; Gadella, T. W. J.; Goedhart, J. A New Generation of FRET Sensors for Robust Measurement of G $\alpha \mathrm{i} 1, \mathrm{G} \alpha \mathrm{i} 2$ and Goi3 Activation Kinetics in Single Cells. PLoS One 2016, 11, No. e0146789.

(39) Harvey, C. D.; Ehrhardt, A. G.; Cellurale, C.; Zhong, H.; Yasuda, R.; Davis, R. J.; Svoboda, K. A Genetically Encoded Fluorescent Sensor of ERK Activity. Proc. Natl. Acad. Sci. U.S.A. 2008, 105, 19264-19269.

(40) Klarenbeek, J.; Goedhart, J.; Van Batenburg, A.; Groenewald, D.; Jalink, K. Fourth-Generation Epac-Based FRET Sensors for CAMP Feature Exceptional Brightness, Photostability and Dynamic Range: Characterization of Dedicated Sensors for FLIM, for Ratiometry and with High Affinity. PLoS One 2015, 10, No. e0122513.

(41) Schwinn, D. A.; Lomasney, J. W.; Lorenz, W.; Szklut, P. J.; Fremeau, R. T.; Yang-Feng, T. L.; Caron, M. G.; Lefkowitz, R. J.; Cotecchia, S. Molecular Cloning and Expression of the CDNA for a Novel A1-Adrenergic Receptor Subtype. J. Biol. Chem. 1990, 265, 8183-8189.

(42) Bünemann, M.; Frank, M.; Lohse, M. J. Gi Protein Activation in Intact Cells Involves Subunit Rearrangement Rather than Dissociation. Proc. Natl. Acad. Sci. U.S.A. 2003, 100, 16077-16082.

(43) Krasel, C.; Bünemann, M.; Lorenz, K.; Lohse, M. J. BetaArrestin Binding to the Beta2-Adrenergic Receptor Requires Both Receptor Phosphorylation and Receptor Activation. J. Biol. Chem. 2005, 280, 9528-9535.

(44) Bodmann, E.-L.; Krett, A.-L.; Bünemann, M. Potentiation of Receptor Responses Induced by Prolonged Binding of $\mathrm{G} \alpha 13$ and Leukemia-Associated RhoGEF. FASEB J. 2017, 31, 3663-3676.

(45) Lemoine, F.; Correia, D.; Lefort, V.; Doppelt-Azeroual, O.; Mareuil, F.; Cohen-Boulakia, S.; Gascuel, O. NGPhylogeny.Fr: New Generation Phylogenetic Services for Non-Specialists. Nucleic Acids Res. 2019, 47, W260-W265.

(46) Adjobo-Hermans, M. J.; Goedhart, J.; van Weeren, L.; Nijmeijer, S.; Manders, E. M.; Offermanns, S.; Gadella, T. W. RealTime Visualization of Heterotrimeric G Protein Gq Activation in Living Cells. BMC Biol. 2011, 9, 32.

(47) Miller, R. T.; Masters, S. B.; Sullivan, K. A.; Beiderman, B.; Bourne, H. R. A Mutation That Prevents GTP-Dependent Activation of the $\alpha$ Chain of Gs. Nature 1988, 334, 712-715.

(48) Bokoch, G. M.; Katada, T.; Northup, J. K.; Hewlett, E. L.; Gilman, A. G. Identification of the Predominant Substrate for ADPRibosylation by Islet Activating Protein. J. Biol. Chem. 1983, 258, 2072-2075.

(49) Jain, R.; Watson, U.; Vasudevan, L.; Saini, D. K. ERK Activation Pathways Downstream of GPCRs. In International Review of Cell and Molecular Biology; Elsevier Inc., 2018; Vol. 338, pp 79109.

(50) Okashah, N.; Wan, Q.; Ghosh, S.; Sandhu, M.; Inoue, A.; Vaidehi, N.; Lambert, N. A. Variable G Protein Determinants of GPCR Coupling Selectivity. Proc. Natl. Acad. Sci. U.S.A. 2019, 116, 12054-12059.

(51) Vilardaga, J. P. Theme and Variations on Kinetics of GPCR Activation/Deactivation. J. Recept. Signal Transduction 2010, 30, 304312.

(52) Grundmann, M.; Merten, N.; Malfacini, D.; Inoue, A.; Preis, P.; Simon, K.; Rüttiger, N.; Ziegler, N.; Benkel, T.; Schmitt, N. K.; Ishida, S.; Müller, I.; Reher, R.; Kawakami, K.; Inoue, A.; Rick, U.; Kühl, T.; Imhof, D.; Aoki, J.; König, G. M.; Hoffmann, C.; Gomeza, J.; Wess, J.; Kostenis, E. Lack of Beta-Arrestin Signaling in the Absence of Active G Proteins. Nat. Commun. 2018, 9, No. 341.

(53) Volkenhoff, A.; Hirrlinger, J.; Kappel, J. M.; Klämbt, C.; Schirmeier, S. Live Imaging Using a FRET Glucose Sensor Reveals Glucose Delivery to All Cell Types in the Drosophila Brain. J. Insect Physiol. 2018, 106, 55-64.

(54) Couto, A.; Oda, S.; Nikolaev, V. O.; Soltesz, Z.; De Bono, M. Vivo Genetic Dissection of O2-Evoked CGMP Dynamics in a 
Caenorhabditis elegans Gas Sensor. Proc. Natl. Acad. Sci. U.S.A. 2013, 110, E3301-E3310.

(55) Sun, F.; Zeng, J.; Jing, M.; Zhou, J.; Feng, J.; Owen, S. F.; Luo, Y.; Li, F.; Wang, H.; Yamaguchi, T.; Yong, Z.; Gao, Y.; Peng, W.; Wang, L.; Zhang, S.; Du, J.; Lin, D.; Xu, M.; Kreitzer, A. C.; Cui, G.; Li, Y. A Genetically Encoded Fluorescent Sensor Enables Rapid and Specific Detection of Dopamine in Flies, Fish, and Mice. Cell 2018, 174, 481-496.

(56) Jing, M.; Li, Y.; Zeng, J.; Huang, P.; Skirzewski, M.; Kljakic, O.; Peng, W.; Qian, T.; Tan, K.; Zou, J.; Trinh, S.; Wu, R.; Zhang, S.; Pan, S.; Hires, S. A.; Xu, M.; Li, H.; Saksida, L. M.; Prado, V. F.; Bussey, T. J.; Prado, M. A. M.; Chen, L.; Cheng, H.; Li, Y. An Optimized Acetylcholine Sensor for Monitoring in Vivo Cholinergic Activity. Nat. Methods 2020, 1-8. 